\title{
Evaluation of Implementation of Blanded Learning Implementation in Universitas Negeri Medan
}

\author{
$\underline{\text { Abdul Hamid K}}{ }^{1}$, Tiur Malsari Siregar ${ }^{2}$, Jamalum Purba ${ }^{3}$, Budi Ali Mukmin ${ }^{4}$ \\ 1Programme of Study in Civil Engineering Education Universitas Negeri Medan, Indonesia \\ 2Programme of Study in Mathematics Education Universitas Negeri Medan, Indonesia \\ 3Programme of Study in Chemistry Education Universitas Negeri Medan, Indonesia \\ 4Programme of Studi in Pancasila and Citizenship Education Study, Indonesia \\ Email: rianiavandi@gmail.com
}

\begin{abstract}
The purpose of this study is to obtain the level of achievement of the evaluation of the implementation of blended learning at Universitas Negeri Medan in terms of the evaluation components, namely system assessment, program planning, program implementation, program improvement, and program certification. Also, get a description of the application of Blended Learning at Universitas Negeri Medan. The sample in this study were representatives of lecturers and students from faculties who carry out learning using the Blended Learning model at Universitas Negeri Medan. The results of the study show that for the evaluation component of the system assessment, it was obtained an average percentage of achievement of $84.03 \%$ so that it was included in the good achievement category. For the evaluation component of the Planning program, it is obtained an average percentage of achievements of $86.9 \%$ so that it is included in the good achievement category. For the Program Implementation evaluation component, the percentage of achievement was an average of $87.3 \%$, so that it was included in the good achievement category. For the evaluation component, the Improvement Program obtained an average percentage of achievement of $91.3 \%$ so that it was included in the very good achievement category. The evaluation component of the Program Certification obtained an average percentage of achievement of $88 \%$ so that it was included in the good achievement category. The implementation of Blended Learning, in general, went well, from the sample taken from the lecturer representatives of each faculty it was found that there had been an adjustment in the RPS with the KKNI assignments in the implementation of blended learning. The most common obstacle is the wifi facilities that have not been maximized. Suggestions are given to make a standard policy for uniformity in the implementation of blended learning at Universitas Negeri Medan.
\end{abstract}

Keywords: evaluation; blanded learning; Universitas Negeri Medan

\section{Introduction}

Higher education is one of the educational institutions in the national education system. Higher education institutions are obliged to carry out education, research, and community service as stipulated in Law Number 20 of 2003 concerning the National Education System (Depdiknas, 2003). The main aim of higher education is to facilitate student learning (Nygaard \& Belluigi, 2011, p.657) [1]. In order to carry out its obligations, tertiary institutions must be supported by synergistic cooperation from all universities.

Medan State University is encouraging its lecturers to provide teaching with the Blended Learning model. The new Permenristek regulations state that the curriculum that applies at the State University of Medan must be adjusted based on the needs of the industrial revolution 4.0. Therefore, in accordance with the mandate of the IQF curriculum that has been implemented at Medan State University, learning activities must use blended learning because e-learning is one way for lecturers and students to use technology.

Blended learning is a knowledge transfer program that utilizes more than one method to provide information to students (Garrison \& kanuka) [2]. Generally, blended learning is 
considered as learning that combines face-to-face systems with mediation technology instruction [3]. In the past, the two learning environments in the blended learning model were still used separately because they used a combination of different media and methods and were used on the needs of different audiences (students) [4]

Nowadays, the term 'blended learning' model is at the stage of combining the two environments above, no longer separate, meaning that there is a time when learning uses the same method, media, and audience, namely by using web-based learning. This is different from the term blended learning model in the future because, in the future, the blended system will dominate more in learning than blended now. This means that face to face learning will be increasingly abandoned. Existing traditional learning systems will increasingly sink with the culture of the learning environment mediated by computer technology and the internet

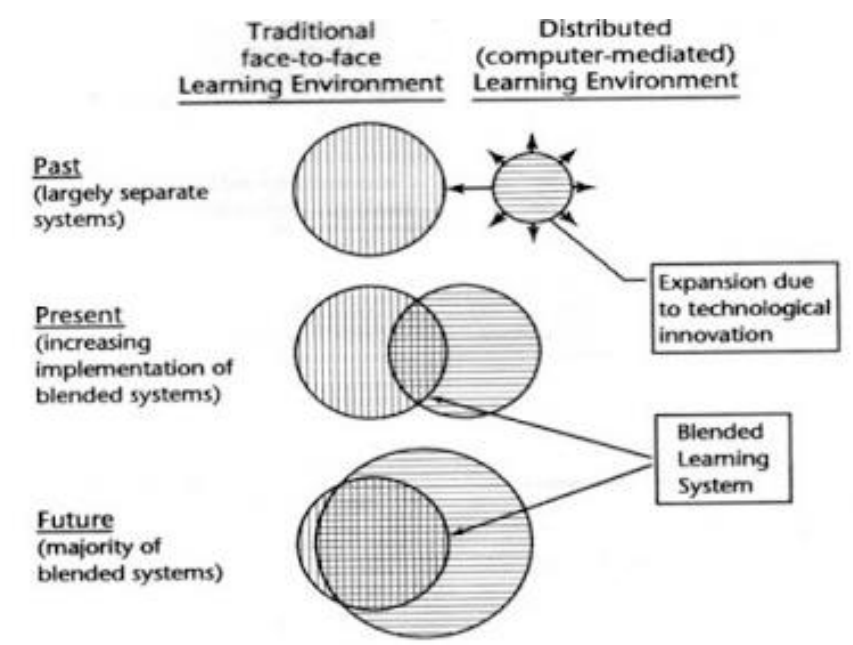

Figure 1. The model of blended learning in the past, present, and future

Blanded Learning is considered capable of being a facility that can help the learning process at Medan State University into learning that can answer the challenges of the Digital Era 4.0. Where in this era, all students and lecturers were demanded to be IT literate. Students who have graduated and want to enter the world of work must be able to compete in all fields. We must be able to follow the rapid progress of the times. This can be seen from various industries starting to touch the virtual world in the form of human, machine, and data connectivity, which is better known as the Internet of Things (IoT). As explained by Dalyono [5] Innovative learning strategies can make it easier to achieve learning competence, being able to attract and arouse student motivation in learning. This assumption is what led to Blended Learning to be an option when learning is not enough just face to face.

Until now, Medan's state universities do not yet have a policy that is implemented as an implementation of the implementation of blended learning. For this reason, an evaluation of the implementation of blended learning is ongoing. Evaluation can be interpreted as a planned activity to find out the state of an object using instruments, and the results are compared with a benchmark to obtain a conclusion. In a broad sense, evaluation is a process of planning, obtaining, and providing information that is needed to make alternative decisions (Mehrens \& Lehman, 1978: 5) [6]. A thorough evaluation of the implementation of blended learning needs to be done so that the implementation of blended learning can later be further optimized [7].

There are some studies behind this research, including research on evaluating the implementation of blended learning at SMK IT Udayana Using the CSE-UCLA Model [7]. In addition, there is research on the effectiveness of blended learning that conveys an experience 
developing blended learning models that are not only valid but also effective at Padang State University, as an effort to expand access to tertiary education and find alternative learning models to overcome various limitations they have. By a higher education institution [8]. Encouraged by the need and also to ensure the accuracy of the running and effectiveness of Blended Learning within the Medan State University, the researchers evaluated the implementation of the Blended Learning model at Medan State University aimed at lecturers and students.

\section{Research Method}

In general, the research method is defined as a scientific way to obtain data with specific purposes and uses. The research method is closely related to the procedures, techniques, tools, and research designs used. Research on evaluating the implementation of the Blended Learning learning process is a descriptive study. Descriptive analysis is research that is intended to gather information about the status of an existing symptom, which is the state of the sign according to what it was at the time of the study. This study aims to obtain a picture of the subject under investigation. The data processing is based on percentage analysis and trend analysis without linking to the population situation where the data was taken. (Dharminto, 2006: 6).

The sample of this study was representatives of lecturers from all faculties and student representatives who carried out Blended Learning at Medan State University. Data collection techniques used in this study include Questionnaires and documentation. The questionnaire has been used through the stages of instrument development to capture responses sourced from lecturers and students who have implemented Blended Learning. For the questionnaire, the implementation of blended learning for lecturers can open the page https://forms.gle/aQKH4tjRytzZVtVM6. And students can open the site https://forms.gle/hSwjZy9FbHiXsuLn8 page. Then the data from the results of the questionnaire are presented and analyzed using descriptive narrative.

The evaluation model used is to develop the evaluation components of the implementation of blended learning as follows in terms of several evaluation components, namely system assessment, program planning, program implementation, program improvement, and program certification.

\section{Result and Discussion}

There are several evaluation components that have been measured in evaluating the implementation of Blended Learning in Medan State University environment, including the component of the Assessment System which includes evaluation of the objectives in the application of blended learning, evaluation of HR needs in the implementation of Blended Learning, and evaluation of environmental support for the implementation of Blended Learning in the environment of Medan State University.

In terms of the Planning Program component, it includes evaluating the readiness of lecturers in carrying out blended learning, evaluating students' readiness in carrying out blended learning, and evaluating the readiness of facilities and infrastructure in implementing blended learning in Medan State University.

In terms of the Program Implementation component which includes evaluating the implementation of the introduction of hardware and software for lecturers and students as 
supporters of the implementation of blended learning and evaluating the use of hardware and software for lecturers and students in carrying out blended learning

In terms of the Improvement program component, which includes an evaluation of how the Blended Learning Operation system is for lecturers and an evaluation of how Blended Learning is Operating for students. In terms of the component of the certification program, which includes an evaluation of the physical appearance of blended learning at their learning in the environment of Medan State University. To make it easier about the components that have been evaluated in the details in Figure 1.

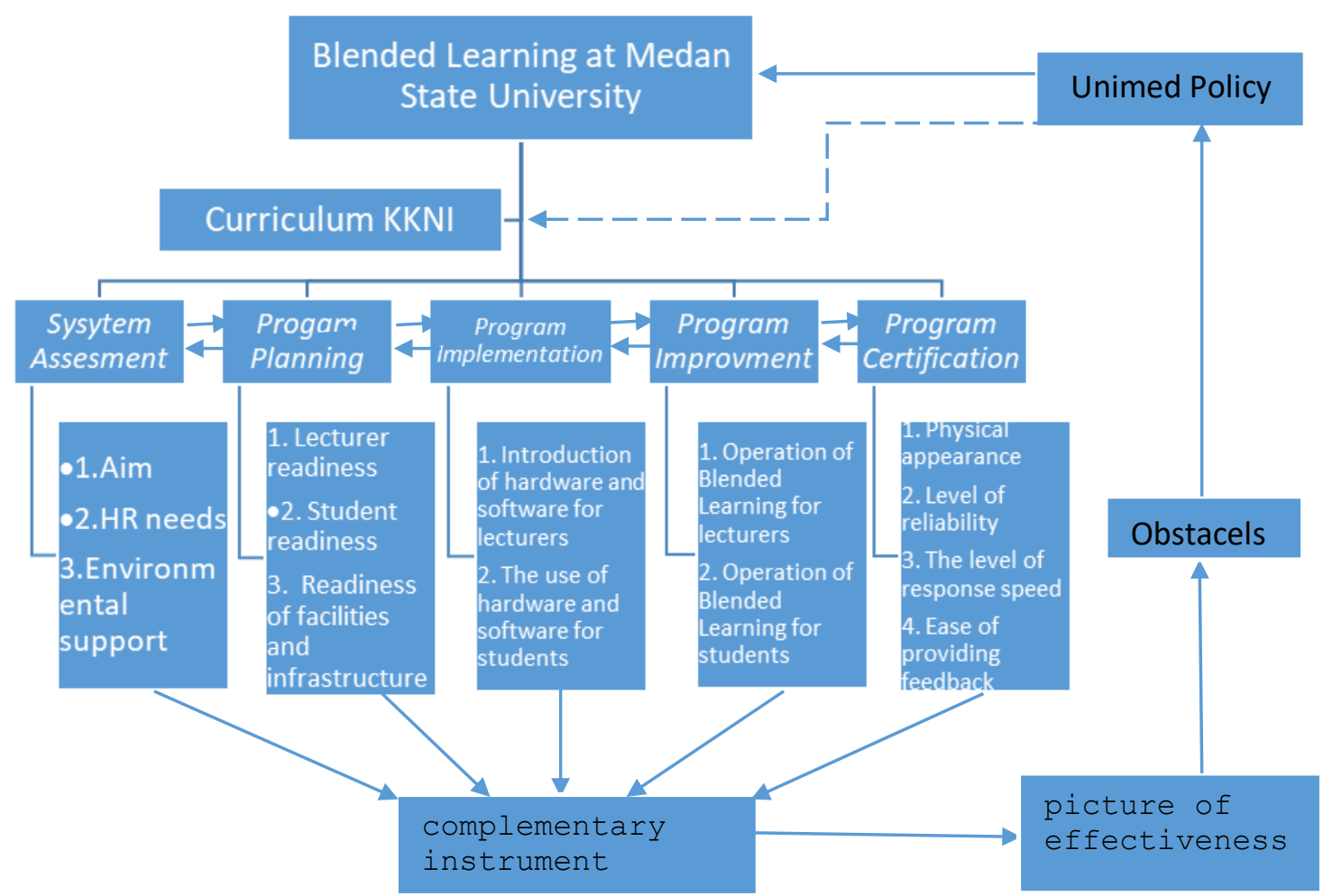

Figure 2. Components and Aspects of the evaluation of the Implementation of Blended Learning at Medan State University

In evaluating the implementation of blended learning, the criteria for the percentage of achievement of the evaluation component of the implementation of blended learning are as follows.

Table 1. Criteria for Achieving Blended Learning

\begin{tabular}{cc}
\hline $\begin{array}{c}\text { Percentage of } \\
\text { Interpretation }\end{array}$ & Achievement \\
\hline $\mathrm{K} \geq 90 \%$ & Very Good \\
$80 \% \leq \mathrm{k}<90 \%$ & Good \\
$70 \% \leq \mathrm{k}<80 \%$ & Enough \\
$60 \% \leq \mathrm{k}<70 \%$ & Not good \\
$\mathrm{K}<60 \%$ & very less \\
\hline
\end{tabular}

In general, the results of evaluations of the implementation of blended learning in the Medan State University in each evaluation component, including the evaluation component of the system assessment, obtained an average percentage of achievement of $84.03 \%$ so that it is 
included in the good achievement category. For the evaluation component of the Planning program, it is obtained an average percentage of achievements of $86.9 \%$ so that it is included in the good achievement category. For the Program Implementation evaluation component, the percentage of achievement was an average of $87.3 \%$, so that it was included in the good achievement category. For the evaluation component, the Improvement Program obtained an average percentage of achievement of $91.3 \%$ so that it was included in the very good achievement category. The evaluation component of the Program Certification obtained an average percentage of achievement of $88 \%$ so that it was included in the good achievement category. The results of evaluating the components of the implementation of blended learning and the aspects evaluated are presented in Table 2.

From the findings of the research, there are several obstacles to the implementation of blended learning in Medan's state university environment. The constraint in terms of the evaluation component of the implementation of blended learning, among others, in the evaluation system System Assessment, in particular, the support of the tertiary state tertiary universities in the implementation of blended learning has been fulfilled but less than the maximum namely the provision of wifi access, not every classroom has been accessed. Sometimes the network speed is also not good.

In the evaluation component of the Planning program, the constraints found were the readiness of students in semester one who still needed mentoring and more time in adjusting to the blended learning system so that learning was running a little less, There were still students who could not operate online learning (still clueless)). Facilities and infrastructure readiness is still limited by the amount of hardware such as mini projector, Obstacles in the evaluation component of the program implementation there are still students who are not familiar with the applications used by lecturers in supporting Blended learning, so that it impacts on the constraints of program improvement in the operation of blended learning. For the lecturers, there were still no problems, because almost all the lecturers who were sampled in this study were proficient in the use of hardware and software for the implementation of blended learning.

From the findings of the research, there are several obstacles to the implementation of blended learning in Medan's state university environment. The constraint in terms of the evaluation component of the implementation of blended learning, among others, in the evaluation system System Assessment, in particular, the support of the tertiary state tertiary universities in the implementation of blended learning has been fulfilled. Still, less than the maximum, namely the provision of wifi access, not every classroom has been accessed. Sometimes the network speed is also not good.

Table 2. Criteria for Achieving the Evaluation Component of Blended Learning Implementation at the Medan State University Environment.

\begin{tabular}{|c|c|c|c|c|}
\hline No & $\begin{array}{l}\text { Evaluation } \\
\text { component }\end{array}$ & Evaluated Aspects & $\begin{array}{l}\text { Evaluation } \\
\text { result }\end{array}$ & $\begin{array}{l}\text { Performance } \\
\text { Criteria }\end{array}$ \\
\hline \multirow[t]{2}{*}{1} & System Assessment & $\begin{array}{ll}\text { - } & \text { Aim } \\
\text { - } & \text { HR needs } \\
\text { - } & \text { Environmental } \\
& \text { support }\end{array}$ & $\begin{array}{l}91,3 \% \\
86,9 \% \\
73,9 \%\end{array}$ & $\begin{array}{l}\text { Very Good } \\
\text { Good } \\
\text { Enough }\end{array}$ \\
\hline & Avera & ge System Assessment & & $84 \%$ ( Good) \\
\hline 2 & Program Planning & $\begin{array}{ll}\text { - } & \text { Lecturer readiness } \\
\text { - } & \text { Student readiness } \\
\text { - } & \text { Readiness of facilities and }\end{array}$ & $\begin{array}{l}91,3 \% \\
82,6 \% \\
86,9 \%\end{array}$ & $\begin{array}{l}\text { Very Good } \\
\text { Good } \\
\text { Good }\end{array}$ \\
\hline
\end{tabular}




\begin{tabular}{|c|c|c|c|c|}
\hline & \multicolumn{3}{|c|}{ Average Program Planning } & \multirow{2}{*}{$\begin{array}{l}86,9 \% \text { ( Good) } \\
\text { Sangat Baik }\end{array}$} \\
\hline 3 & $\begin{array}{l}\text { Program } \\
\text { Implementation }\end{array}$ & $\begin{array}{l}\text { - Introduction of hardware } \\
\text { and software for lecturers } \\
\text { - The use of hardware and } \\
\text { software for students }\end{array}$ & $78,9 \%$ & \\
\hline & Aver: & Program Implementation & & $87,3 \%$ ( Baik) \\
\hline 4 & $\begin{array}{l}\text { Program } \\
\text { Improvement }\end{array}$ & $\begin{array}{l}\text { Operation of Blended } \\
\text { Learning for lecturers } \\
\text { - Operation of Blended } \\
\text { Learning for students }\end{array}$ & $\begin{array}{l}95,7 \% \\
86,9 \%\end{array}$ & $\begin{array}{l}\text { Very good } \\
\text { Good }\end{array}$ \\
\hline & Ave & e Program Improvement & & 91,3\% (Very Good) \\
\hline 5 & $\begin{array}{l}\text { Program } \\
\text { Certification }\end{array}$ & $\begin{array}{ll}\text { - } & \text { Physical appearance } \\
\text { - } & \text { Level of reliability } \\
\text { - The level of response } & \text { speed } \\
\text { - } & \text { Ease of providing } \\
& \text { feedback } \\
\end{array}$ & $\begin{array}{l}86,9 \% \\
86,9 \% \\
86,9 \% \\
91,3 \%\end{array}$ & $\begin{array}{l}\text { Good } \\
\text { Good } \\
\text { Good } \\
\text { Very Good }\end{array}$ \\
\hline
\end{tabular}

In the evaluation component of the Planning program, the constraints found were the readiness of students in semester one who still needed mentoring and more time in adjusting to the blended learning system so that learning was running a little less, There were still students who could not operate online learning (still clueless)). Facilities and infrastructure readiness is still limited by the amount of hardware such as mini projector, Obstacles in the evaluation component of the program implementation there are still students who are not familiar with the applications used by lecturers in supporting Blended learning, so that it impacts on the constraints of program improvement in the operation of blended learning. For the lecturers, there were still no problems, because almost all the lecturers who were sampled in this study were proficient in the use of hardware and software for the implementation of blended learning.

From the description of the results of the evaluation questionnaire, it was found that the results of the implementation of blended learning from the sample taken as whole lecturers have run blended learning. Each lecturer who did the teaching had explained the application of blended learning in the RPS design so that there was a match between the RPS and the implementation in the field. Some supporting media used by lecturers in conducting blended learning, especially online learning, include SIPDA that has been provided by Unimed, Moodle, Google classroom, Video Conference, Whatsapp, YouTube, Edmodo, and many more. The absence of standard rules regarding the implementation of blended learning results in differences in implementation, especially in the percentage between the number of online and offline meetings.

How lecturers conduct, affective, cognitive, and psychomotor assessments are also still diverse. Adjustment of KKNI assignments is also included in terms of assessment to students. Lecturers conduct affective assessments, among others, by looking at student activities in class, both question and answer sessions, assignment presentations, discussions, student activity in the network, and also timeliness in the collection of assignments. Cognitive assessment is done through giving assignments in person or online, quizzes, or written examinations. As for the psychomotor evaluation, the methods conducted by the lecturers include direct meeting 
assessments seen from the assignment presentation, through project assignments and also through proficiency in using online media.

In terms of the level of recovery, attendance from lecturers, and students during the implementation of blended learning can be fulfilled in the range of $90 \%-100 \%$. This is because of the ease of placement of time in online learning makes every lecture session can be fulfilled. Due to the importance of network utilization in the effort to implement blended learning, however the lack of signal bandwidth in the learning environment is unimportant, so it becomes one of the inhibiting factors in the implementation of blended learning. The university has provided wifi facilities for the Unimed community, but sometimes it cannot be accessed in the classroom. The purpose of providing networks with the aim that online learning can be done by students in class and also when face to face can directly integrate with online learning. Also needed additional facilities and infrastructure units that support direct learning in class, such as in focus.

The response given by students to the implementation of blended learning was also very positive. Students like to experience learning that opens more broad horizons because they have to be more diligent in seeking material knowledge from cyberspace and expanding knowledge in today's developing world of technology. According to students, the instructions given by the lecturers were quite clear, but there were still $36.5 \%$ of students who had difficulty understanding the material if given online and had to get deepening face to face. There are $36.8 \%$ of the sample of students who are still having difficulty following online learning due to a lack of supporting facilities if they are outside campus or from home.

Supporting factors in the implementation of blended learning include the availability of SIPDA, which is one of the online learning media for lecturers, the policy of each faculty that advises each lecturer to carry out blended learning, and also facilitates lecturers to participate in a blended learning workshop. Even adjustments to the demands of the IQF curriculum especially tasks integrated into the implementation of blended learning.

\section{Conclusion}

The conclusion that can be drawn from the results of this study is that, in general, the category of achieving the evaluation of the implementation of blended learning has gone well. For the evaluation component of the system assessment, the average percentage obtained was $84.03 \%$, so that it was included in the good performance category. For the evaluation component of the Planning program, it is obtained an average percentage of achievements of $86.9 \%$ so that it is included in the good achievement category. For the Program Implementation evaluation component, the percentage of achievement was an average of $87.3 \%$, so that it was included in the good achievement category. For the evaluation component, the Improvement Program obtained an average percentage of achievement of $91.3 \%$ so that it was included in the very good achievement category. The evaluation component of the Program Certification obtained an average percentage of achievement of $88 \%$ so that it was included in the good achievement category.

Although in general, it works well but there are still obstacles in the implementation of blended learning in Medan's state university environment including the provision of wifi access that has not yet reached all classes, learning facilities that are still lacking in class and there are still students who need more guidance in using online learning networks. Students have been able to take part in blended learning, only the difficulty of students is there is still limited access to online learning because some of them are internet facilities that are not always fulfilled, 
individual equipment that is not supportive for some students, lack of student confidence in interacting directly or even social media / internet.

As for suggested, among others, the need for socialization and standard rules or blended learning implementation policies in Medan state universities. It aims to make the uniform implementation of blended learning, both from the number of online and face-to-face meetings, uniformity in affective, cognitive and psychomotor assessments, and also the availability of SIPDA administrators who are alert. To improve and strengthen the quality of human resources, especially lecturers regular blended learning workshops are needed at Unimed.

\section{References}

Retnowati TH, et.al , 2017, Model evaluasi kinerja dosen: pengembangan instrumen untuk mengevaluasi kinerja dosen J Penelit dan Eval Pendidik. 2017;21(2):206. doi:10.21831/pep.v21i2.16626

[Shroff R dan Vogel D, 2010, An Investigation on Individual Students' Perceptions of Interest Utilizing a Blended Learning Approach, International Jl. on E-Learning , 9 (2), 279-294

So dan Bonk C , 2017, Examining the Roles of Blended Learning Approaches in ComputerSupported Collaborative Learning (CSCL) Environments: A Delphi Study, jornal of Educational Technology \& Society

Zuvic, M., Roncevic, N., Nemcanin, D. 2011. Blended e-learning in higher education: Research on students' perspective. Issues in Informing Science and Information Technology.4(8), 410-428. Tersedia pada iisit. org/Vol8 /IISITv8p409-429 Zuvic 247. pdf.

Dalyono, B. 2016 Strategi Pembelajaran Inovatif Untuk Mencapai Kompetensi Pembelajaran , Temu Ilmiah Nasional Guru VIII Tahun 2016: Tantangan Profesionalisme Guru di Era Digital, 26 November 2016, Balai Sidang Universias Terbuka (UTCC).

Purwanto, Ngalim. (2010). "Prinsip-Prinsip Dan Teknik Evaluasi Pengajaran”. Bandung : PT Remaja Rosdakarya

Divayana, 2017, Evaluasi pelaksanaan blended learning di SMK TI Udayana menggunakan model CSE-UCLA, Jurnal Pendidikan Vokasi Volume 7, No 1, Februari 2017 (64-77)

Effendi, Z.M, (2016) Efektifitas Blended Learning Dalam Meningkatkan Akses Belajar Di LPTK, Konvensi Nasional Pendidikan Indonesia (KONASPI) VIII Tahun 2016 